\title{
RNA modularity for synthetic biology
}

\author{
Wade Grabow $^{1 *}$ and Luc Jaeger ${ }^{2 *}$
}

\author{
Addresses: ${ }^{1}$ Department of Chemistry and Biochemistry, Seattle Pacific University, 3307 Third Avenue West, Seattle, WA 98119, USA; ${ }^{2}$ Department \\ of Chemistry and Biochemistry, Bio-Molecular Science and Engineering Program, University of California, Santa Barbara, CA 93106-9510, USA \\ *Corresponding authors: Wade Grabow (grabow@spu.edu); Luc Jaeger (jaeger@chem.ucsb.edu) \\ Fl000Prime Reports 2013, 5:46 (doi:10.12703/P5-46) \\ This is an open-access article distributed under the terms of the Creative Commons Attribution-Non Commercial License \\ (http://creativecommons.org/licenses/by-nc/3.0/legalcode), which permits unrestricted use, distribution, and reproduction in any medium, \\ provided the original work is properly cited. You may not use this work for commercial purposes. \\ The electronic version of this article is the complete one and can be found at: http://fl 000.com/prime/reports/b/5/46
}

\begin{abstract}
RNA molecules are highly modular components that can be used in a variety of contexts for building new metabolic, regulatory and genetic circuits in cells. The majority of synthetic RNA systems to date predominately rely on two-dimensional modularity. However, a better understanding and integration of three-dimensional RNA modularity at structural and functional levels is critical to the development of more complex, functional bio-systems and molecular machines for synthetic biology applications.
\end{abstract}

\section{Introduction}

In the broadest sense, synthetic biology attempts to understand and mimic biological systems in order to provide novel biologically inspired solutions for a variety of challenges, such as medicine, energy production and product manufacturing. RNAs, such as short interfering RNAs (siRNAs), aptamers, riboswitches and ribozymes, hold significant promise as modular components for developing regulatory genetic circuits and other biological tools for many synthetic biology applications [1-10]. As exemplified by complex cellular machineries, like the ribosome [11-13], RNase P RNAs [14,15], group I and group II introns [16-19] and the spliceosome [20,21], RNA is a material of choice for building complex, functional nano-architectures $[22,23]$. The number of reviews highlighting the remarkable progress achieved in RNA synthetic biology over the past few years points to this [24-28]. However, when compared to the variety, and structural and functional complexity of natural systems, RNA synthetic biology still has a tremendous way to go.

A key structural attribute of RNA relates to its inherent ability to form diverse tertiary interactions through noncanonical base-pairings [29]. In this regard, the biologically relevant or active structure of an RNA molecule most often has three-dimensional implications. While significant gains have been made in RNA synthetic biology using nothing more than the knowledge of an RNA secondary structure as the primary determinant of activity in vitro [30-34], transition to the vastly more complex cellular context can still present unforeseen challenges for these same RNA moieties [35,36]. Some of this difficulty may stem from the construction of large artificial RNA-based systems and devices that lack a critical degree of structural and functional robustness. Thus, in our view, further developments in RNA synthetic biology complexityincluding genetic regulatory elements, signaling devices, and molecular architectures-will depend on more focused efforts to understand and incorporate RNA structural principles at the tertiary level. Operating under this supposition, the following report is limited to more recent developments inspired by RNA nano-technology that offer opportunities to construct RNA devices or biosystems containing significant increases in structural and functional complexity for use in RNA synthetic biology.

\section{Structural and functional parts from naturally occurring RNAs}

Similar to the other fundamental biomolecules, RNA is a hierarchical molecule containing multiple levels of modularity $[37,38]$ (see Figure 1). The first and most basic layer of modularity at the chemical level concerns the four nucleotide building blocks themselves, which may be mixed and matched in any arrangement to form primary sequences. At the next level, the formation of regular 
Figure I. The multiple degrees of modularity in biological systems

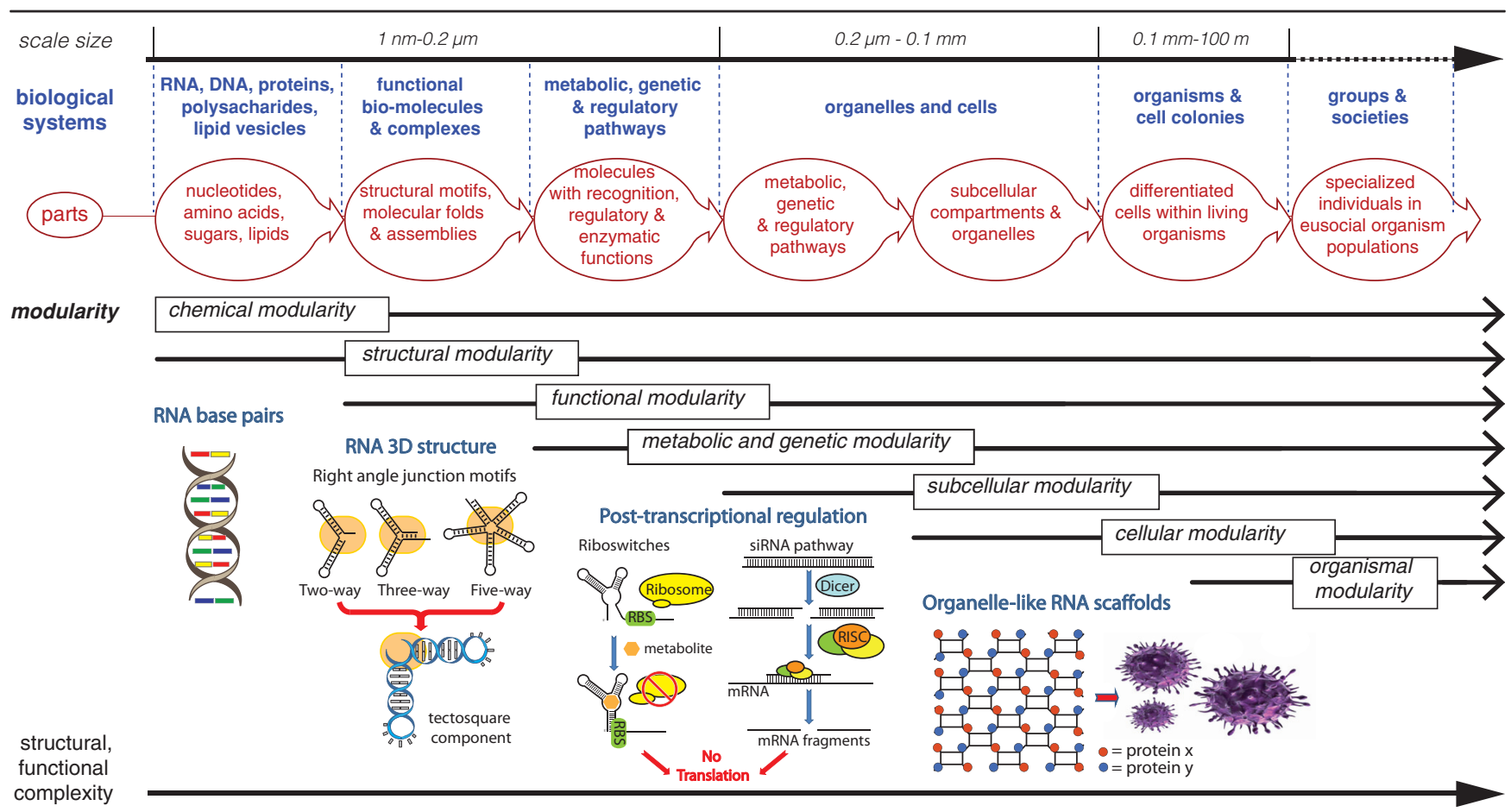

As an example, RNAs are chemically, structurally and functionally modular. They can be integrated at the level of multiple metabolic, genetic and regulatory pathways that are themselves parts of subcellular components or cellular units. At a higher level of integration, RNA regulatory circuits are involved in the cellular modularity of multicellular organisms and in the developmental mechanisms leading to the specialization of individual organisms. Individual organisms can themselves be parts within colonies of eusocial species.

Watson-Crick helices that define RNA secondary (2D) structures constitutes the most basic form of structural modularity. The utility of $2 \mathrm{D}$ structure modularity has been demonstrated through the fusion of various types of RNA aptamers to other functional RNA elementsproviding the regulatory RNAs (i.e. siRNAs and microRNAs [miRNAs]) with the ability to selectively target specific cell types or allosterically respond to environmental metabolites [39-41]. This type of modularity gives RNA synthetic biology a "plug-and-play" quality that facilitates the design of modular composite devices. This important capability allows different sequence modules to be swapped in and out to tailor the specific activities encoded in a particular device without needing to redesign the linkages between the modules of the device each time to maintain functional activity. Although presently less utilized in RNA synthetic biology, the same type of modularity is found at the tertiary level of RNA structures. It is at this highest level that structural modularity involves the three-dimensional (3D) nature of RNAs and their tertiary motifs.

Tertiary RNA motifs consist of highly conserved canonical and non-canonical hydrogen bonding patterns between semi-conserved nucleotides. The majority of tertiary motif information to date has come from the structural data of large naturally occurring RNAs, like the ribosome, group I intron, and RNase P. Characterization of recurrent hydrogen bonding patterns has led to the identification of a variety of recurrent structural motifs, including small submotifs (e.g. the U-turn [42], A-minor and GA-minor motifs [37,43-44], the UA_handle [38] and the ribose zipper [45]), terminal and internal loops [38,46-51], turns and junctions [37,38,52-59], longrange interactions [60-65] and pseudoknots [38,66-67]. A unifying characteristic of tertiary RNA motifs relates to their ability to also operate in a "plug-and-play" type fashion. Properly understood, RNA motifs can be swapped in and out of different sequence contexts and maintain their structural 3D identities $[38,68]$.

Until recently, the use of tertiary RNA motifs (at least as far as it relates to synthetic biology) has been generally limited to the design of artificial RNA assemblies for the construction of RNA nano-structures, nano-particles (NPs) and/or scaffolds [5,6,43,68-73]. Because folded RNAs can be decomposed into smaller tertiary motifs, these structural building blocks can be used for 
engineering artificial molecular units (tectoRNAs) able to self-assemble into large nano-structures $[5,22,23,68]$. This foundational approach, called RNA architectonics, was employed to generate in vitro (in the test tube) selfassembling RNA filaments (1D), RNA planar arrays (2D) and RNA polyhedral NPs (3D) with precise control and positioning of functional components in 3D space (e.g. $[5,10,23,68,72-77])$. Such work has demonstrated that tertiary motifs, forming thermodynamically stable and well-defined topologies, can be isolated and inserted into a variety of artificial structural contexts without compromise. By unraveling the sequence-structure relationship for RNA tertiary folds (e.g. $[38,43,59])$, the toolkit for rationally designing and constructing more complex and larger modular RNA assemblies is beginning to be established [78-80].

With respect to the more complex naturally occurring RNAs (i.e. the ribosome and RNase P), tertiary motifs are the core structural elements that facilitate folding and assembly as well as molecular recognition, and enzymatic and/or regulatory functions. In the case of smaller, less complex RNAs, the relationship between RNA structure and RNA function remains unchanged, in that structural modularity leads to functional modularity. For example, RNA takes advantage of a variety of structural contexts to regulate the expression of genes-ranging from riboswitches to small anti-sense RNA regulators (Figure 1) $[27,28]$. This ability is greatly facilitated by functional modularity. While different RNA folds can have different functions, structurally different RNAs can share identical or similar regulatory functions. The usage of different structural modules with identical functions as well as the mixing and matching of different RNA functions is a key component of natural RNA biology. This same principle will certainly facilitate the design of novel metabolic and genetic regulatory pathways by customizing them to particular structural, genomic contexts and organisms (Figure 1). Additionally, the interchangeability of different functional RNA parts could also be used to unravel and discover new principles of functional equivalence between apparently distinct cellular operations [81,82]. Therefore, rather than being limited to generating new divergent synthetic pathways in cells, we anticipate that synthetic biology will also contribute to the functional convergence and modularity of molecular circuits and metabolic pathways at the origin of the buildup of cells and organisms $[81,82]$.

RNA parts from directed selection and evolution The ability to generate novel RNAs with virtually any specific predetermined phenotype, using directed evolution and in vitro selection, has been instrumental in RNA nano-technology and RNA synthetic biology $[83,84]$. In this regard, SELEX (systematic evolution of ligands by exponential enrichment) has become the strategy of choice for the directed evolution and selection of RNA having novel binding and/or catalytic properties [85-89]. From a structural perspective, in vitro selection offers the possibility of creating new structural motifs, not selected for in natural systems, including novel long-range interactions (e.g. $[65,77,90-91])$. The possibility of selecting new RNA interactions and shapes significantly increases our ability to create more complex nanostructures and nano-machines. One consequence of its success relates to the relative ease associated with generating new phenotypes compared to the time and effort it takes to thoroughly ascertain the structural characteristics of each new aptamer selected $[92,93]$. The ultimate goal of directed evolution strategies is often, at times, more concerned with generating a specific desired phenotype from a pool of sequences of rather short sizes than it is with characterizing the resulting RNA's unique structural features.

Recently, Wittmann and Seuss [36] pointed out that, despite the number and diversity of RNA aptamers isolated to date $[94,95]$, only a limited number of artificially selected aptamers have been successfully incorporated into useful riboswitch applications. They suggest that a majority of aptamers selected for in vitro lack the structural complexity necessary to function reliably in vivo. For example, when placed in the context of a regulatory element like a natural riboswitch, neomycinbinding aptamers screened in vivo have greater functional activity than those initially isolated in vitro $[96,97]$. Aptamers selected for in vivo regulation, like the tetracycline aptamer $[36,98]$, tend to have increased structural complexity-allowing for larger conformational changes, higher binding-affinity with fast ligand binding and slow release, and greater thermal stability upon ligand binding [36]. It is possible that increased structural complexity may generate sequences that can support more interactions with the target ligand. This in turn could lead to higher binding affinity and/or increased binding specificity, which could explain the greater activity in vivo where ligand concentrations are likely to be more limited. Without knowing the precise cause, such findings, nevertheless, suggest that the selective pressures present in vivo give rise to aptamers with greater structural complexity and overall increased robustness, which may in turn allow them to work more effectively in these same conditions.

Structural studies on a variety of natural riboswitches suggest that long-range tertiary interactions are fundamental to their functional activity [99-103]. The important contributions that long-range interactions make in riboswitches (with respect to functional activity) are 
reminiscent of past research involving the minimal hammerhead ribozyme. Over a decade of research based on the minimal hammerhead sequence provided inconclusive information on its active structure until the fulllength ribozyme structure was discovered and its atomic structure solved, revealing a long-range interaction [104]. At first sight, isolation by in vivo SELEX of structurally complex aptamers might appear challenging but it is sure to offer greater potential for synthetic biology applications in comparison to many minimalist aptamers primarily selected for binding affinity in vitro. Furthermore, because evolution and selection often lead to the isolation of more than one RNA fold able to carry the same function, conducting selection experiments in vivo may increase the potential to produce multiple solution sets having the desired functional activity in vivo. Isolating multiple RNA solutions (each having functional modularity between the structurally distinct and unrelated 3D structures) promises to enhance the potential for building up more complex RNA molecules by providing additional structural choices among a specific type of function.

The inherently modular nature of RNA has spawned the study of RNA structures generated from completely random nucleotide sequences devoid of any selection pressures. These "never born RNAs" investigate the sequence/structure space associated with random RNA sequences not tied to selection pressures (whether natural or unnatural) $[105,106]$. In addition to highlighting how a particular structure can arise from many unrelated and different RNA sequences, "never born RNAs" could provide important insight into the ways in which the emergence of RNA structures are influenced by selection pressures-or the lack thereof. The use of structured "never born RNAs" as scaffolds could hold the promise of generating new devices with new or novel functionalities, but will most importantly contribute to unraveling the underlying sequence and structural constraints that are important in the selection and design of novel RNA functions for biological applications.

\section{RNA parts with enhanced biomolecular interoperability for greater complexity}

Future advancements in RNA synthetic biology will require greater interoperability between RNA and other types of materials. With respect to DNA and proteins, RNA offers distinct advantages. RNA is highly compatible with DNA in that it can form predictable base-pairings. In this regard, RNA can be used to form complex 2D circuits with itself and/or with DNA [107-109]. Furthermore, it can regulate and be naturally transcribed from DNA templates in vivo. Besides coding for proteins, RNA can co-operate with proteins to form ribonucleo-protein (RNP) complexes for regulation (i.e. in transcription and translation) and for building complex functional cellular machineries (i.e. the ribosome and RNase P).

As the technologies and methods for the selection of artificial RNA aptamers targeting proteins continue to advance [110], so do their applications. RNA aptamers targeting specific proteins have been used for applications including controlled localization of RNA [111], visualization of cellular RNA [112], and directing metabolic pathways through the use of engineered RNA scaffolds [7]. On the other hand, several RNP complexes have been designed to develop responsive genetic switches and reprogram cellular behavior [113-118]. The elucidation of the binding rules between RNA and Pumilio and FBF homology protein (PUF) [119-121] and pentatricopeptide repeats [122] offers interesting possibilities for the rational design of novel RNP constructs that can work in conjunction with one another [123].

Some natural non-coding RNAs, like DsrA, have the potential to form large RNA architectures within bacterial cells [124-126]. In the same manner, it was demonstrated that rationally designed RNA self-assembling nanostructures could promote the organization of intracellular reactions to produce an artificial hydrogen-producing pathway in bacteria (e.g. [7]). In view of these results and the potential of RNP complexes to generate self-assemblies [127], the development of novel intracellular RNP functions associated with subcellular self-assembling structures seems limitless for synthetic biology.

\section{Chemically modified RNA parts and synthetic ligands}

One of the areas where RNA synthetic biology has truly embraced its "synthetic" side is in the area of synthetic chemistry. Chemically modified RNA nucleotides and hybrids containing non-natural nucleic acids offer distinct possibilities in addition to their ability to increase an RNA's chemical and/or enzymatic stability. Non-natural nucleic acids (also referred to as XNA) have the potential to expand RNA's functional diversity as well as the ability to offer orthogonal systems capable of replication, heredity, and evolution [128-130]. As in vitro evolution and selection of novel functional XNAs has been recently demonstrated [129-131], XNAs open the door to the engineering of truly artificial living systems based on polymers other than DNA, RNA and proteins. Biocompatible XNAs containing reactive groups capable of undergoing enzyme-free ligation reactions [132] and nucleic acids containing photo-responsive moieties [133] are other examples of expanded functionality. Additionally, unmodified RNAs have been selected for their ability to bind synthetic small molecules or ligands in order to induce fluorescence signals $[8,134,135]$. 
As areas of RNA synthetic biology become more and more synthetic, structural and functional considerations of new synthetic parts will need to be continually re-investigated. For example, their effects on molecular recognition and assembly will determine the ways in which they can ensure seamless biocompatibility with existing cellular processes, such as self-assembly, regulation, and transcription processes.

\section{The rise of nano-machines and RNA synthetic biology}

The engineering of complex molecular nano-machines offers us the prospect of being able to modify, repair and/ or control cellular operations for various therapeutic purposes. Their development may also increase the present toolkit of molecular biology and biochemistry for circularizing, modifying or synthesizing RNA and novel informational polymers. Recently, DNA self-assembly was used for engineering several mechanical devices, artificial nano-machines and assembly lines (e.g. [136140]). However, these DNA nano-machines are still far from the remarkable efficiency and complexity of natural cellular machines, which essentially rely on RNA and proteins. Presently, one strategy for building nanomachines consists of deriving new functionalities from existing RNA machines like the ribosome. The creation of orthogonal ribosomes, operated by an expanded genetic code and using four codons per amino acid represents one of these seminal achievements for synthetic biology [141143]. Other strategies take advantage of directed evolution and in vitro selection to isolate new complex artificial ribozymes from random RNA libraries (e.g. [144-146]), or modular RNA libraries that consist of a pre-existing functional domain to which random loops are appended (e.g. [85,147-151]). While a great deal of novel functional RNAs have been isolated by directed evolution and in vitro selection from combinatorial libraries of $30 \mathrm{nts}$ to $200 \mathrm{nts}$ (e.g. [85-87]), their structural and functional complexity are still far from that observed in nature (Figure 2). Presently, one of the most advanced nano-machines selected is a $200 \mathrm{nt}$ RNA polymerase ribozyme (tC19z) with enhanced polymerase activity and fidelity with respect to previous class I ribozymes from which it was derived $[150,152,153]$ (Figure 2). However, the resulting $\mathrm{tC} 19 \mathrm{z}$ ribozyme is still partially template sequencedependent and relatively slow (RNA polymerization reactions occur over several days [152]), in contrast to those catalyzed by RNA polymerase proteins that require only minutes to copy much longer templates. The question is whether nano-machines with the functional and structural complexity of large natural ribozymes can be developed in the laboratory. If they can, it will be a significant milestone paving the way to complex nanofactories with great potential for synthetic biology.
Figure 2. Structural complexity of natural and artificial ribozymes and RNA nano-structures in function of sequence length

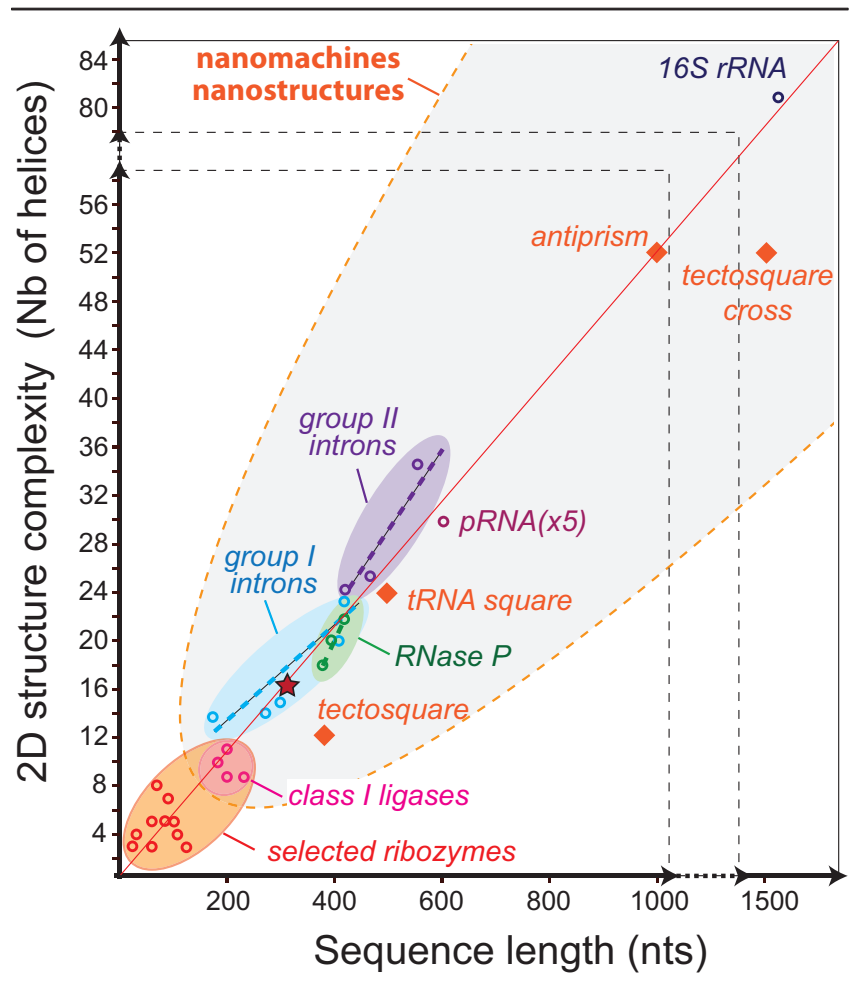

A reasonable estimate of the two-dimensional (2D) structural complexity of a folded RNA is its number of constituent Watson-Crick helices. Note that most natural ribozymes and the $16 \mathrm{~S}$ ribosomal RNA (rRNA) are aligned. In vitro selected ribozymes are circled in orange. Class I ligases are the most complex ribozymes originating from purely random sequences $[146,150,152,153]$. The red star indicates the most complex RNA ligase isolated by SELEX from a partially random library based on a natural structural scaffold [|47,I5I]. Diamonds indicate modular nano-structures (reported in [68,72-73]).

As the functional complexity of natural molecular machines is proportional to their structural complexity (Figure 2), we hypothesize that the current knowledge in RNA nano-structure design will provide a foundation for building larger artificial nano-machines that approach the functional complexity of natural ones. Because of technical limitations associated with synthesizing large random RNA pools and RNA precipitation, functional parts isolated from purely random pools is limited to less than $200 \mathrm{nts}$ regions (e.g. [144-146]). With the RNA architectonics approach, it is possible to engineer much larger RNA nano-structures or modular parts that can be used as scaffolds for pre-orienting and positioning random loops in 3D space, thereby allowing isolation of functional modules within large structural contexts that are not accessible from purely random pools (e.g. [147150]. Thus, we anticipate that combining RNA 
architectonics with directed evolution and in vitro selection would allow new modular ribozymes with structural complexity comparable to those of large ribozymes (i.e. group I and group II introns, RNase P) to be isolated. Additionally, selection pressure could be applied to select directional moving parts with functional modules to work in a concerted fashion to achieve a particular functional task. At the present time, the de novo development of complex nano-machines that operate in cells is exciting but essentially uncharted territory in synthetic biology.

\section{Prospects and questions}

Recent advances in RNA synthetic biology present fascinating possibilities but also raise a number of intriguing questions. For example, to what degree is structural complexity required for implementing complex cellular behaviors? It is true that rather simple molecules like miRNAs, siRNAs, or antisense RNAhaving limited complexity at the part level-offer enough control to enable a great variety of different cellular behaviors. At the same time it is also clear, from the vantage point of both artificial and natural RNAs, that increased structural complexity has its advantages in certain cases. This seems to be particularly true when it comes to creating RNAs with interesting chemistry (as in the case of the ribosome) or selective RNAs having multiple functionalities (as in the case of riboswitches that require specific binding and allosteric regulatory properties).

The identification and characterization of large noncoding RNAs (lncRNAs) presents a new and emerging frontier in which to explore the correlation between structural and functional complexity further. Recent profiling of the secondary structure of some lncRNAs, on the order of several hundred nucleotides, suggests that they fold into complex highly ordered conformations [154-157]. While the degree to which IncRNAs form RNP complexes remains to be seen, at least three possible structural scenarios regarding their possible interactions have been put forth [158]. It would seem that whether lncRNAs exist as compact cores with largely peripheral protein binding sites, as relatively unstructured RNAs with loosely organized protein binding domains, or as RNAs lacking a central core but with ordered protein binding sites would be the result of very different and distinct folding and structural principles. For instance, compact 3D RNAs would most likely need to rely on and be optimized for long-range tertiary interactions while the other two would be optimized to avoid long-range tertiary interactions. Uncovering some of these fundamental characteristics regarding these types of structures could provide further insights into the design of synthetic RNP particles [71,123] and/or reveal unknown functionalities. Ultimately, such findings have the potential to advance our understanding of modern biology as well as provide new tools and strategies for RNA synthetic biology.

\section{Abbreviations}

lncRNA, large noncoding RNA; PUF, Pumilio and FBF homology protein; RNP, ribonucleo-protein; SELEX, systematic evolution of ligands by exponential enrichment; XNA, non-natural nucleic acid.

\section{Disclosures}

None.

\section{Acknowledgments}

Luc Jaeger wishes to dedicate this paper to Saint Thomas the Apostle, patron saint of architects and great missionary, and to Our Lady of Expectation.

\section{References}

I. Guo P: The emerging field of RNA nanotechnology. Nat Nanotechnol 2010, 5:833-42.

2. Heidel JD, Davis ME: Clinical developments in nanotechnology for cancer therapy. Pharm Res 201 I, 28:187-99.

3. Davis ME, Zuckerman JE, Choi CHJ, Seligson D, Tolcher A, Alabi CA, Yen $Y$, Heidel JD, Ribas A: Evidence of RNAi in humans from systemically administered siRNA via targeted nanoparticles. Nature 2010, 464:1067-70.

\section{FlOOOPrime}

RECOMMENDED

4. Guo P, Coban O, Snead NM, Trebley J, Hoeprich S, Guo S, Shu Y: Engineering RNA for targeted siRNA delivery and medical application. Adv Drug Deliv Rev 2010, 62:650-66.

5. Grabow WW, Zakrevsky P, Afonin KA, Chworos A, Shapiro BA, Jaeger L: Self-assembling RNA nanorings based on RNAI/II inverse kissing complexes. Nano Lett 20 I I, I I:878-87.

6. Tarapore P, Shu Y, Guo P, Ho S: Application of phi29 motor pRNA for targeted therapeutic delivery of siRNA silencing metallothionein-IIA and survivin in ovarian cancers. Mol Ther 2011, I 9:386-94.

7. Delebecque CJ, Lindner AB, Silver PA, Aldaye FA: Organization of intracellular reactions with rationally designed RNA assemblies. Science 201 I, 333:470-4.

FlOOOPrime

RECOMMENDED

8. Paige JS, Wu KY, Jaffrey SR: RNA mimics of green fluorescent protein. Science 20II, 333:642-6.

\section{FlOOOPrime}

RECOMMENDED

9. Lee JB, Hong J, Bonner DK, Poon Z, Hammond PT: Self-assembled RNA interference microsponges for efficient siRNA delivery. Nat Mater 2012, I I:316-22.

\section{FlOOOPrime}

RECOMMENDED

10. Afonin KA, Grabow WW, Walker FM, Bindewald E, Dobrovolskaia MA, Shapiro BA, Jaeger L: Design and self-assembly of siRNA-functionalized RNA nanoparticles for use in automated nanomedicine. Nat Protoc 20I I, 6:2022-34.

II. Ramakrishnan V: Unraveling the structure of the ribosome (Nobel Lecture). Angew Chem Int Ed Engl 2010, 49:4355-80. 
12. Steitz TA: From the structure and function of the ribosome to new antibiotics (Nobel Lecture). Angew Chem Int Ed Engl 2010, 49:4381-98.

13. Yonath A: Polar bears, antibiotics, and the evolving ribosome (Nobel Lecture). Angew Chem Int Ed Engl 2010, 49:434l-54.

14. Massire C, Jaeger L, Westhof E: Derivation of the threedimensional architecture of bacterial ribonuclease P RNAs from comparative sequence analysis. J Mol Biol 1998, 279:773-93.

15. Torres-Larios A, Swinger KK, Pan T, Mondragón A: Structure of ribonuclease P-a universal ribozyme. Curr Opin Struct Biol 2006, 16:327-35.

16. Jaeger L, Westhof E, Michel F: Monitoring of the cooperative unfolding of the sunY group I intron of bacteriophage T4. The active form of the sunY ribozyme is stabilized by multiple interactions with $3^{\prime}$ terminal intron components. J Mol Biol 1993, 234:331-46.

17. Lehnert V, Jaeger L, Michel F, Westhof E: New loop-loop tertiary interactions in self-splicing introns of subgroup IC and ID: a complete 3D model of the Tetrahymena thermophila ribozyme. Chem Biol 1996, 3:993-1009.

18. Toor N, Keating KS, Fedorova O, Rajashankar K, Wang J, Pyle AM: Tertiary architecture of the Oceanobacillus iheyensis group II intron. RNA 2010, 16:57-69.

19. Stahley MR, Strobel SA: RNA splicing: group I intron crystal structures reveal the basis of splice site selection and metal ion catalysis. Curr Opin Struct Biol 2006, 16:319-26.

20. Sander B, Golas MM, Makarov EM, Brahms H, Kastner B, Lührmann R, Stark H: Organization of core spliceosomal components U5 snRNA loop I and U4/U6 Di-snRNP within U4/U6.U5 TrisnRNP as revealed by electron cryomicroscopy. Mol Cell 2006, 24:267-78.

\section{FlOOOPrime} RECOMMENDED

21. Ohi MD, Ren L, Wall JS, Gould KL, Walz T: Structural characterization of the fission yeast U5.U2/U6 spliceosome complex. Proc Natl Acad Sci USA 2007, I 04:3195-200.

22. Westhof E, Masquida B, Jaeger L: RNA tectonics: towards RNA design. Fold Des 1996, I:R78-88

23. Jaeger $L$, Chworos $A$ : The architectonics of programmable RNA and DNA nanostructures. Curr Opin Struct Biol 2006, | 6:53 |-43.

24. Benenson Y: Synthetic biology with RNA: progress report. Curr Opin Chem Biol 2012, 16:278-84.

25. Isaacs FJ, Dwyer DJ, Collins J]: RNA synthetic biology. Nat Biotechnol 2006, 24:545-54.

\section{FlOOOPrime
RECOMMENDED}

26. Saito H, Inoue T: Synthetic biology with RNA motifs. Int J Biochem Cell Biol 2009, 41:398-404.

27. Liang JC, Bloom RJ, Smolke CD: Engineering biological systems with synthetic RNA molecules. Mol Cell 20I I, 43:9I5-26.

28. Lioliou E, Romilly C, Romby P, Fechter P: RNA-mediated regulation in bacteria: from natural to artificial systems. $N$ Biotechnol 2010, 27:222-35.

29. Butcher SE, Pyle AM: The molecular interactions that stabilize RNA tertiary structure: RNA motifs, patterns, and networks. Acc Chem Res 201 I, 44:I302-II.

\section{FIOOOPrime}

\section{RECOMMENDED}

30. Ceres P, Garst AD, Marcano-Velázquez JG, Batey RT: Modularity of select riboswitch expression platforms enables facile engineering of novel genetic regulatory devices. ACS Synth Biol 2013, 2:463-72.

31. Lucks JB, Qi L, Mutalik VK, Wang D, Arkin AP: Versatile RNAsensing transcriptional regulators for engineering genetic networks. Proc Natl Acad Sci USA 201 I, 108:8617-22.
32. Storz G, Vogel J, Wassarman KM: Regulation by small RNAs in bacteria: expanding frontiers. Mol Cell 20I I, 43:880-9I

\section{FlOOOPrime
RECOMMENDED}

33. Callura JM, Cantor CR, Collins J: Genetic switchboard for synthetic biology applications. Proc Natl Acad Sci USA 2012, 109:5850-5.

34. Rodrigo G, Landrain TE, Jaramillo A: De novo automated design of small RNA circuits for engineering synthetic riboregulation in living cells. Proc Natl Acad Sci USA 2012, 109:1527|-6.

35. Kashida S, Inoue T, Saito H: Three-dimensionally designed protein-responsive RNA devices for cell signaling regulation. Nucleic Acids Res 2012, 40:9369-78.

36. Wittmann A, Suess B: Engineered riboswitches: Expanding researchers' toolbox with synthetic RNA regulators. FEBS Lett 2012, 586:2076-83.

FIOOOPrime
RECOMMENDED

37. Grabow WW, Zhuang Z, Shea J, Jaeger L: The GA-minor submotif as a case study of RNA modularity, prediction, and design. Wiley Interdiscip Rev RNA 2013, 4:181-203.

38. Jaeger L, Verzemnieks EJ, Geary C: The UA_handle: a versatile submotif in stable RNA architectures. Nucleic Acids Res 2009 37:215-30.

39. Beisel CL, Chen YY, Culler SJ, Hoff KG, Smolke CD: Design of small molecule-responsive microRNAs based on structural requirements for Drosha processing. Nucleic Acids Res 201I, 39:2981-94.

\section{FlOOOPrime}

RECOMMENDED

40. McNamara JO, Andrechek ER, Wang Y, Viles KD, Rempel RE, Gilboa E, Sullenger BA, Giangrande PH: Cell type-specific delivery of siRNAs with aptamer-siRNA chimeras. Nat Biotechnol 2006 , 24: $1005-15$.

\section{FlOOOPrime}

\section{RECOMMENDED}

4I. Vinkenborg JL, Karnowski N, Famulok M: Aptamers for allosteric regulation. Nat Chem Biol 20I I, 7:519-27.

42. Gutell RR, Cannone J], Konings D, Gautheret D: Predicting U-turns in ribosomal RNA with comparative sequence analysis. J Mol Biol 2000, 300:791-803.

\section{FlOOOPrime}

\section{RECOMMENDED}

43. Geary C, Chworos A, Jaeger L: Promoting RNA helical stacking via A-minor junctions. Nucleic Acids Res 201 I, 39:1066-80

44. Nissen P, Ippolito JA, Ban N, Moore PB, Steitz TA: RNA tertiary interactions in the large ribosomal subunit: the A-minor motif. Proc Natl Acad Sci USA 200I, 98:4899-903.

\section{FIOOOPrime
RECOMMENDED}

45. Tamura M, Holbrook SR: Sequence and structural conservation in RNA ribose zippers. J Mol Biol 2002, 320:455-74.

\section{FlOOOPrime \\ RECOMMENDED}

46. Lee JC, Cannone JJ, Gutell RR: The lonepair triloop: a new motif in RNA structure. J Mol Biol 2003, 325:65-83.

\section{FlOOOPrime}

RECOMMENDED

47. Lisi V, Major F: A comparative analysis of the triloops in all high-resolution RNA structures reveals sequence structure relationships. RNA 2007, I3:1537-45.

48. Correll CC, Beneken J, Plantinga MJ, Lubbers M, Chan Y: The common and the distinctive features of the bulged-G motif based on a 1.04 A resolution RNA structure. Nucleic Acids Res 2003, $31: 6806-18$. 
49. Leontis NB, Stombaugh J, Westhof E: Motif prediction in ribosomal RNAs Lessons and prospects for automated motif prediction in homologous RNA molecules. Biochimie 2002, 84:96I-73.

50. Krasilnikov AS, Mondragón A: On the occurrence of the T-loop RNA folding motif in large RNA molecules. RNA 2003, 9:640-3.

51. Nagaswamy U, Fox GE: Frequent occurrence of the T-loop RNA folding motif in ribosomal RNAs. RNA 2002, 8: I I I2-9.

52. Klein DJ, Moore PB, Steitz TA: The roles of ribosomal proteins in the structure assembly, and evolution of the large ribosomal subunit. J Mol Biol 2004, 340:141-77.

\section{FlOOOPrime \\ RECOMMENDED}

53. Rázga F, Zacharias M, Réblová K, Koca J, Sponer J: RNA kink-turns as molecular elbows: hydration, cation binding, and largescale dynamics. Structure 2006, 14:825-35.

54. Szép S, Wang J, Moore PB: The crystal structure of a 26-nucleotide RNA containing a hook-turn. RNA 2003, 9:44-51.

\section{FlOOOPrime}

\section{RECOMMENDED}

55. Wadley LM, Pyle AM: The identification of novel RNA structural motifs using COMPADRES: an automated approach to structural discovery. Nucleic Acids Res 2004, 32:6650-9.

\section{FlOOOPrime}

56. Steinberg SV, Boutorine YI: G-ribo: a new structural motif in ribosomal RNA. RNA 2007, 13:549-54.

\section{FlOOOPrime}

\section{RECOMMENDED}

57. Lescoute A, Westhof $E$ : Topology of three-way junctions in folded RNAs. RNA 2006, 12:83-93.

58. Laing $C$, Schlick $T$ : Analysis of four-way junctions in RNA structures. J Mol Biol 2009, 390:547-59.

59. Grabow WW, Zhuang Z, Swank ZN, Shea J, Jaeger L: The right angle (RA) motif: a prevalent ribosomal RNA structural pattern found in group I introns. J Mol Biol 2012, 424:54-67.

60. Ennifar E, Walter P, Ehresmann B, Ehresmann C, Dumas P: Crystal structures of coaxially stacked kissing complexes of the HIV-I RNA dimerization initiation site. Nat Struct Biol 200I, 8:1064-8.

61. Brunel C, Marquet R, Romby P, Ehresmann C: RNA loop-loop interactions as dynamic functional motifs. Biochimie 2002, 84:925-44.

62. Gagnon MG, Steinberg SV: GU receptors of double helices mediate tRNA movement in the ribosome. RNA 2002, 8:873-7.

\section{FlOOOPrime} RECOMMENDED

63. Mokdad A, Krasovska MV, Sponer J, Leontis NB: Structural and evolutionary classification of $\mathbf{G} / \mathbf{U}$ wobble basepairs in the ribosome. Nucleic Acids Res 2006, 34: I326-4I.

64. Costa M, Michel F: Rules for RNA recognition of GNRA tetraloops deduced by in vitro selection: comparison with in vivo evolution. EMBO J 1997, 16:3289-302.

65. Geary C, Baudrey S, Jaeger L: Comprehensive features of natural and in vitro selected GNRA tetraloop-binding receptors. Nucleic Acids Res 2008, 36: I I38-52.

66. Staple DW, Butcher SE: Pseudoknots: RNA structures with diverse functions. PLoS Biol 2005, 3:e2 I3.

67. Steinberg SV, Boutorine YI: G-ribo motif favors the formation of pseudoknots in ribosomal RNA. RNA 2007, 13:1036-42.

68. Severcan I, Geary C, Verzemnieks E, Chworos A, Jaeger L: Squareshaped RNA particles from different RNA folds. Nano Lett 2009, 9:1270-7.
69. Dibrov SM, McLean J, Parsons J, Hermann T: Self-assembling RNA square. Proc Natl Acad Sci USA 20I I, 108:6405-8.

70. Guo P, Shu Y, Binzel D, Cinier M: Synthesis, conjugation, and labeling of multifunctional pRNA nanoparticles for specific delivery of siRNA, drugs, and other therapeutics to target cells. Methods Mol Biol 2012, 928:197-219.

7I. Ohno H, Kobayashi T, Kabata R, Endo K, Iwasa T, Yoshimura SH, Takeyasu K, Inoue T, Saito H: Synthetic RNA-protein complex shaped like an equilateral triangle. Nat Nanotechnol 20II, 6: $116-20$.

72. Severcan I, Geary C, Chworos A, Voss N, Jacovetty E, Jaeger L: A polyhedron made of tRNAs. Nat Chem 2010, 2:772-9.

73. Chworos A, Severcan I, Koyfman AY, Weinkam P, Oroudjev E, Hansma HG, Jaeger L: Building programmable jigsaw puzzles with RNA. Science 2004, 306:2068-72.

\section{FlOOOPrime \\ RECOMMENDED}

74. Jaeger, Leontis: Tecto-RNA: One-Dimensional Self-Assembly through Tertiary Interactions This work was carried out in Strasbourg with the support of grants to N.B.L. from the NIH (IRI5 GM55898) and the NIH Fogarty Institute (I-F06TW0225I-0I) and the support of the CNRS to L.J. The authors wish to thank Eric Westhof for his support and encouragement of this work. Angew Chem Int Ed Engl 2000, 39:2521-4

75. Nasalean L, Baudrey S, Leontis NB, Jaeger L: Controlling RNA selfassembly to form filaments. Nucleic Acids Res 2006, 34:I38I-92.

\section{FlOOOPrime}

\section{RECOMMENDED}

76. Afonin KA, Bindewald E, Yaghoubian AJ, Voss N, Jacovetty E, Shapiro BA, Jaeger L: In vitro assembly of cubic RNA-based scaffolds designed in silico. Nat Nanotechnol 2010, 5:676-82.

77. Afonin KA, Lin Y, Calkins ER, Jaeger L: Attenuation of loopreceptor interactions with pseudoknot formation. Nucleic Acids Res 20I2, 40:2168-80.

78. Kasprzak W, Bindewald E, Kim T, Jaeger L, Shapiro BA: Use of RNA structure flexibility data in nanostructure modeling. Methods 20II, 54:239-50.

79. Bindewald E, Afonin K, Jaeger L, Shapiro BA: Multistrand RNA secondary structure prediction and nanostructure design including pseudoknots. ACS Nano 20I I, 5:9542-5 I.

80. Alterovitz G, Benson R, Ramoni M (Eds): Automation in Proteomics and Genomics. Chichester, UK: John Wiley \& Sons, Ltd; 2009.

8I. Jaeger L, Calkins ER: Downward causation by information control in micro-organisms. Interface Focus 20I2, 2:26-4I.

82. Auletta G, Ellis GFR, Jaeger L: Top-down causation by information control: from a philosophical problem to a scientific research programme. J $R$ Soc Interface 2008, 5: I I59-72.

83. Gold L, Janjic N, Jarvis T, Schneider D, Walker JJ, Wilcox SK, Zichi D: Aptamers and the RNA world, past and present. Cold Spring Harb Perspect Biol 20I2, 4.

84. Kang K, Lee $Y$ : RNA aptamers: a review of recent trends and applications. Adv Biochem Eng Biotechnol 2013, I3 I:153-69.

85. Hall B, Micheletti JM, Satya P, Ogle K, Pollard J, Ellington AD: Design, synthesis, and amplification of DNA pools for in vitro selection. Curr Protoc Nucleic Acid Chem 2009, 9:Unit 9.2.

86. Chen X, Li N, Ellington AD: Ribozyme catalysis of metabolism in the RNA world. Chem Biodivers 2007, 4:633-55.

\section{FlOOPrime}

\section{RECOMMENDED}

87. Jaeger L: The New World of ribozymes. Curr Opin Struct Biol 1997 7:324-35

88. Zimmermann B, Bilusic I, Lorenz C, Schroeder R: Genomic SELEX: a discovery tool for genomic aptamers. Methods 2010, 52: I25-32.

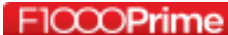


89. Sefah K, Shangguan D, Xiong X, O'Donoghue MB, Tan W: Development of DNA aptamers using Cell-SELEX. Nat Protoc 2010, 5:1169-85.

\section{FlOOOPrime}

\section{RECOMMENDED}

90. Ishikawa J, Furuta $\mathrm{H}$, Ikawa $\mathrm{Y}$ : An in vitro-selected RNA receptor for the GAAC loop: modular receptor for non-GNRA-type tetraloop. Nucleic Acids Res 2013, 41:3748-59.

91. Watrin M, Dausse E, Lebars I, Rayner B, Bugaut A, Toulmé J: Aptamers targeting RNA molecules. Methods Mol Biol 2009, 535:79-105.

\section{FlOOOPrime}

92. Hoinka J, Zotenko E, Friedman A, Sauna ZE, Przytycka TM: Identification of sequence-structure RNA binding motifs for SELEX-derived aptamers. Bioinformatics 2012, 28:i2 I5-23.

\section{FlOOOPrime}

93. Ruigrok VJB, Levisson M, Hekelaar J, Smidt H, Dijkstra BW, van der Oost J: Characterization of Aptamer-Protein Complexes by X-ray Crystallography and Alternative Approaches. Int J Mol Sci 2012, 13:10537-52.

94. Barrick JE, Breaker RR: The distributions, mechanisms, and structures of metabolite-binding riboswitches. Genome Biol 2007, 8:R239.

95. Roth A, Breaker RR: The structural and functional diversity of metabolite-binding riboswitches. Annu Rev Biochem 2009, 78:305-34.

96. Schmidtke SR, Duchardt-Ferner E, Weigand JE, Suess B, Wöhnert J: NMR resonance assignments of an engineered neomycinsensing riboswitch RNA bound to ribostamycin and tobramycin. Biomol NMR Assign 2010, 4:1 I5-8.

\section{FlOOOPrime \\ RECOMMENDED}

97. Weigand JE, Sanchez M, Gunnesch E, Zeiher S, Schroeder R, Suess B: Screening for engineered neomycin riboswitches that control translation initiation. RNA 2008, 14:89-97.

\section{FlOOOPrime}

\section{RECOMMENDED}

98. Xiao H, Edwards TE, Ferré-D'Amaré AR: Structural basis for specific, high-affinity tetracycline binding by an in vitro evolved aptamer and artificial riboswitch. Chem Biol 2008, I5: I 25-37.

99. Schroeder KT, Daldrop P, Lilley DMJ: RNA tertiary interactions in a riboswitch stabilize the structure of a kink turn. Structure 2011, 19:1233-40.

100. Severcan I, Geary C, Jaeger L, Bindewald E, Kasprzak W, Shapiro BA: Computational and Experimental RNA Nanoparticle Design. In Automation in Proteomics and Genomics. Edited by Alterovitz G, Benson R, Ramoni M. Chichester, UK: John Wiley \& Sons, Ltd; 2009:193-220.

10I. Schwalbe H, Buck J, Fürtig B, Noeske J, Wöhnert J: Structures of RNA switches: insight into molecular recognition and tertiary structure. Angew Chem Int Ed Engl 2007, 46:1212-9.

102. Serganov A, Huang L, Patel DJ: Structural insights into amino acid binding and gene control by a lysine riboswitch. Nature 2008, 455: I $263-7$.

103. Serganov A: The long and the short of riboswitches. Curr Opin Struct Biol 2009, 19:25|-9.

104. Martick M, Scott WG: Tertiary contacts distant from the active site prime a ribozyme for catalysis. Cell 2006, 126: 309-20.

FlOOOPrime

RECOMMENDE

105. Chiarabelli C, Stano P, Anella F, Carrara P, Luisi PL: Approaches to chemical synthetic biology. FEBS Lett 20I2, 586:2/38-45.

106. Lucrezia D de, Franchi M, Chiarabelli C, Gallori E, Luisi PL: Investigation of de novo totally random biosequences, Part
IV: Folding Properties of de novo, totally random RNAs. Chem Biodivers 2006, 3:869-77.

FlOOOPrime

107. Benenson Y: RNA-based computation in live cells. Curr Opin Biotechnol 2009, 20:47I-8.

108. Benenson Y: Biomolecular computing systems: principles, progress and potential. Nat Rev Genet 20I2, 13:455-68.

109. Smolke CD, Silver PA: Informing biological design by integration of systems and synthetic biology. Cell 20I I, I44:855-9.

I 10. Ascano M, Gerstberger S, Tuschl T: Multi-disciplinary methods to define RNA-protein interactions and regulatory networks. Curr Opin Genet Dev 2013, 23:20-8.

III. Belmont BJ, Niles JC: Inducible control of subcellular RNA localization using a synthetic protein-RNA aptamer interaction. PLOS ONE 20I2, 7:e46868.

\section{FlOOOPrime
RECOMMENDED}

I 12. Valencia-Burton M, McCullough RM, Cantor CR, Broude NE: RNA visualization in live bacterial cells using fluorescent protein complementation. Nat Methods 2007, 4:42I-7.

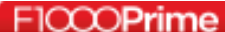

\section{POCOPMTN}

13. Hara T, Saito H, Inoue T: Directed evolution of a synthetic RNAprotein module to create a new translational switch. Chem Commun (Camb.) 20I3, 49:3833-5.

II4. Stapleton JA, Endo K, Fujita Y, Hayashi K, Takinoue M, Saito H, Inoue $\mathrm{T}$ : Feedback control of protein expression in mammalian cells by tunable synthetic translational inhibition. ACS Synth Biol 2012, I:83-8.

I 15. Saito H, Fujita Y, Kashida S, Hayashi K, Inoue T: Synthetic human cell fate regulation by protein-driven RNA switches. Nat Commun 201I, 2:160.

\section{FlOOOPrime}

RECOMMENDED

116. Saito $H$, Kobayashi T, Hara T, Fujita $Y$, Hayashi K, Furushima $R$, Inoue T: Synthetic translational regulation by an L7Ae-kinkturn RNP switch. Nat Chem Biol 2010, 6:71-8.

117. Saito $H$, Inoue T: RNA and RNP as new molecular parts in synthetic biology. J Biotechnol 2007, 132:I-7.

II8. Culler SJ, Hoff KG, Smolke CD: Reprogramming cellular behavior with RNA controllers responsive to endogenous proteins. Science 2010, 330:125I-5.

\section{FlOOOPrime}

\section{RECOMMENDED}

119. Chen $Y$, Varani G: Finding the missing code of RNA recognition by PUF proteins. Chem Biol 20II, I 8:82I-3.

120. Filipovska $A$, Rackham $O$ : Modular recognition of nucleic acids by PUF, TALE and PPR proteins. Mol Biosyst 2012, 8: 699-708.

121. Filipovska A, Razif MFM, Nygård KKA, Rackham O: A universal code for RNA recognition by PUF proteins. Nat Chem Biol 20I I, 7:425-7.

\section{FlOOOPrime RECOMMENDED}

122. Barkan A, Rojas M, Fujii S, Yap A, Chong YS, Bond CS, Small I: A combinatorial amino acid code for RNA recognition by pentatricopeptide repeat proteins. PLoS Genet 20I2, 8:el 002910.

\section{FlOOOPrime
RECOMMENDED}

123. Yamashita K, Tanaka T, Furuta H, Ikawa Y: TectoRNP: selfassembling RNAs with peptide recognition motifs as templates for chemical peptide ligation. J Pept Sci 20I2, I8:635-42.

124. Busi F, Cayrol B, Lavelle C, LeDerout J, Piétrement O, Le Cam E, Geinguenaud F, Lacoste J, Régnier P, Arluison V: Auto-assembly as 
a new regulatory mechanism of noncoding RNA. Cell Cycle 2009, 8:952-4.

\section{FIOOOPrime}

125. Cayrol B, Geinguenaud F, Lacoste J, Busi F, Le Dérout J, Piétrement O, Le Cam E, Régnier P, Lavelle C, Arluison V: Auto-assembly of E. coli DsrA small noncoding RNA: Molecular characteristics and functional consequences. RNA Biol 2009, 6:434-45.

\section{FlOOPrime}

\section{RECOMMENDED}

126. Cayrol B, Nogues C, Dawid A, Sagi I, Silberzan P, Isambert H: A nanostructure made of a bacterial noncoding RNA. J Am Chem Soc 2009, | 3 |: | 17270-6.

\section{FlOOOPrime \\ RECOMMENDED}

127. Ohno H, Kobayashi T, Kabata R, Endo K, Iwasa T, Yoshimura SH, Takeyasu K, Inoue T, Saito H: Synthetic RNA-protein complex shaped like an equilateral triangle. Nat Nanotechnol 20II, 6: I 16-20

128. Appella DH: Non-natural nucleic acids for synthetic biology. Curr Opin Chem Biol 2009, I3:687-96.

129. Pinheiro VB, Loakes D, Holliger P: Synthetic polymers and their potential as genetic materials. Bioessays 20l3, 35: I I3-22.

130. Pinheiro VB, Taylor Al, Cozens C, Abramov M, Renders M, Zhang S, Chaput JC, Wengel J, Peak-Chew S, McLaughlin SH, Herdewijn P, Holliger P: Synthetic genetic polymers capable of heredity and evolution. Science 2012, 336:34I-4.

\section{FlOOOPrime} RECOMMENDED

131. Pinheiro VB, Holliger P: The XNA world: progress towards replication and evolution of synthetic genetic polymers. Curr Opin Chem Biol 2012, 16:245-52.

132. El-Sagheer AH, Brown T: Click nucleic acid ligation: applications in biology and nanotechnology. Acc Chem Res 2012, 45:1258-67.

133. Jäschke A: Genetically encoded RNA photoswitches as tools for the control of gene expression. FEBS Lett 20I2, 586:2 I06-II.

134. Babendure JR, Adams SR, Tsien RY: Aptamers switch on fluorescence of triphenylmethane dyes. J Am Chem Soc 2003, I25:|47|6-7.

\section{FlOOOPrime} RECOMMENDED

135. Reif R, Haque F, Guo P: Fluorogenic RNA nanoparticles for monitoring RNA folding and degradation in real time in living cells. Nucleic Acid Ther 2012, 22:428-37.

136. Gu H, Chao J, Xiao S, Seeman NC: A proximity-based programmable DNA nanoscale assembly line. Nature 2010, 465:202-5.

\section{FlOOOPrime \\ RECOMMENDED}

137. Omabegho T, Sha R, Seeman NC: A bipedal DNA Brownian motor with coordinated legs. Science 2009, 324:67-7I.

138. Lund K, Manzo AJ, Dabby N, Michelotti N, Johnson-Buck A, Nangreave J, Taylor S, Pei R, Stojanovic MN, Walter NG, Winfree $\mathrm{E}$, Yan $\mathrm{H}$ : Molecular robots guided by prescriptive landscapes. Nature 2010, 465:206-10.

I39. Teller C, Willner I: Functional nucleic acid nanostructures and DNA machines. Curr Opin Biotechnol 2010, 21 :376-91.

140. Maune HT, Han S, Barish RD, Bockrath M, lii WAG, Rothemund PWK, Winfree E: Self-assembly of carbon nanotubes into two-dimensional geometries using DNA origami templates. Nat Nanotechnol 2010, 5:6I-6.

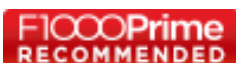

|4I. Wang K, Schmied WH, Chin JW: Reprogramming the genetic code: from triplet to quadruplet codes. Angew Chem Int Ed Engl 20I2, 5 I:2288-97.

142. Neumann H, Wang K, Davis L, Garcia-Alai M, Chin JW: Encoding multiple unnatural amino acids via evolution of a quadrupletdecoding ribosome. Nature 2010, 464:44I-4.

FIOOOPrime
RECOMMENDED

143. Rackham O, Chin JW: A network of orthogonal ribosome $\mathbf{x}$ mRNA pairs. Nat Chem Biol 2005, I:I59-66.

144. Ekland EH, Szostak JW, Bartel DP: Structurally complex and highly active RNA ligases derived from random RNA sequences. Science 1995, 269:364-70.

145. Unrau PJ, Bartel DP: RNA-catalysed nucleotide synthesis. Nature 1998, 395:260-3.

146. Bartel DP, Szostak JW: Isolation of new ribozymes from a large pool of random sequences [see comment]. Science 1993, $261:|4| \mid-8$.

147. Jaeger L, Wright MC, Joyce GF: A complex ligase ribozyme evolved in vitro from a group I ribozyme domain. Proc Natl Acad Sci USA 1999, 96:14712-7.

I48. Yoshioka W, Ikawa Y, Jaeger L, Shiraishi H, Inoue T: Generation of a catalytic module on a self-folding RNA. RNA 2004, 10:1900-6.

149. Ikawa $Y$, Tsuda $K$, Matsumura S, Inoue T: De novo synthesis and development of an RNA enzyme. Proc Natl Acad Sci USA 2004 I 0 I: | 3750-5

FlOOOPrime

150. Johnston WK, Unrau PJ, Lawrence MS, Glasner ME, Bartel DP: RNAcatalyzed RNA polymerization: accurate and general RNAtemplated primer extension. Science 2001, 292:13|9-25.

\section{FlOOOPrime}

\section{RECOMMENDED}

15I. McGinness KE, Joyce GF: RNA-catalyzed RNA ligation on an external RNA template. Chem Biol 2002, 9:297-307.

152. Wochner A, Attwater J, Coulson A, Holliger P: Ribozyme-catalyzed transcription of an active ribozyme. Science 20I I, 332:209-I2.

\section{FlOOOPrime
RECOMMENDED}

153. Zaher HS, Unrau PJ: Selection of an improved RNA polymerase ribozyme with superior extension and fidelity. RNA 2007 I3:1017-26.

FlOOOPrime

154. Novikova IV, Hennelly SP, Sanbonmatsu KY: Structural architecture of the human long non-coding RNA, steroid receptor RNA activator. Nucleic Acids Res 2012, 40:5034-5I.

I55. Puerta-Fernandez E, Barrick JE, Roth A, Breaker RR: Identification of a large noncoding RNA in extremophilic eubacteria. Proc Natl Acad Sci USA 2006, I03:19490-5.

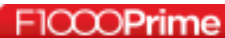

\section{RECOMMENDED}

I56. Wallace JG, Zhou Z, Breaker RR: OLE RNA protects extremophilic bacteria from alcohol toxicity. Nucleic Acids Res 2012, 40:6898-907.

157. Weinberg Z, Perreault J, Meyer MM, Breaker RR: Exceptional structured noncoding RNAs revealed by bacterial metagenome analysis. Nature 2009, 462:656-9.

I58. Novikova IV, Hennelly SP, Tung C, Sanbonmatsu KY: Rise of the RNA Machines: Exploring the Structure of Long Non-Coding RNAs. J Mol Biol 2013, 425:3731-46.

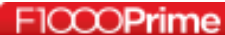

